\title{
Farmers' approaches on occupational health and safety: the case of city of Osmaniye and Konya, Turkey
}

\section{Nermin Bahşi ${ }^{1^{*}}$ (iD) Osman Kendi ${ }^{1}$ (iD}

${ }^{1}$ Department of Organic Farming Business Management, Kadirli School of Applied Sciences, Osmaniye Korkut Ata University, 80760, Turkey. E-mail: nerminbahsi@osmaniye.edu.tr. "Correponding author.

ABSTRACT: The aim of this study was to investigate the knowledge levels of farmers who operate in agricultural activities. This activityconsidered among the most dangerous sectors in Turkey and around the world, on occupational accidents and diseases, occupational health and safety (OHS). The other objective was to learn about farmers' thoughts and contribute to raise awareness and disseminate of occupational health and safety, in Osmaniye and Konya provinces where intensive agricultural activities take place. For this purpose, a faceto-face interview was conducted with 185 farmers in Osmaniye and Konya provinces. According to the survey results, $45.9 \%$ of the farmers stated that they had no idea about occupational health and safety, while only $24.3 \%$ of them had occupational health and safety education. There are statistically significant differences in farmers' age and learning status, their views on occupational health and safety, and their knowledge of occupational health and safety obligations in agriculture. More awareness on occupational health and safety in the agricultural sector should be established. Information and education activities should be carried out to minimize risks and dangers.

Key words: agriculture, occupational accidents, occupational diseases, hazards, knowledge level.

Abordagens dos agricultores sobre saúde e segurança ocupacional: o caso da cidade de Osmaniye e Konya, Turquia

RESUMO: O objetivo deste estudo foi investigar os níveis de conhecimento de agricultores que atuam em atividades agrícolas. Esta atividade é consideradauma das atividades mais perigosas na Turquia e em todo o mundo, em acidentes e doenças profissionais, em saúde e segurança. $O$ outro objetivo era aprender sobre os pensamentos dos agricultores e contribuir para conscientizar e disseminarsaúde e segurança ocupacional, nas províncias de Osmaniye e Konya, onde ocorrem atividades agrícolas intensivas. Para tanto, entrevistas foramrealizadas com 185 agricultores nas províncias de Osmaniye e Konya. De acordo com os resultados da pesquisa, 45,9\% dos agricultoresafirmaram que não tinham ideia sobre saúde e segurança ocupacional, enquanto apenas 24,3\% deles tinham educação em saúde e segurança ocupacional. Existem diferenças estatisticamente significativas na idade dos agricultores e no status de aprendizagem, suas opiniões sobre saúde e segurança ocupacional, e conhecimento das obrigações de saúde ocupacional e segurança na agricultura. Maior conscientização sobre saúde ocupacional e segurança na agricultura no setor deve ser estabelecida. Atividades de informação e educação devem ser realizadas para minimizar riscos e perigos..

Palavras-chave: agricultura, acidentes ocupacionais, doenças ocupacionais, riscos, nível de conhecimento.

\section{INTRODUCTION}

Each sector has different working areas and conditions. They operate within the characteristics of the industry in order to achieve the objectives of the enterprises, and the structures and cultures of the enterprises are formed in this frame. Unlike other sectors, agricultural activities usually involve activities carried out by family members and which also vary according to the level of production of employees' living standards.

Besides, they are among the rare sectors that are generally maintained as family businesses and where business and home life cannot be separated from each other by specific lines (CAMURCU \&
SEYHAN, 2015). Accordingly, employees carry out their vital activities as well as production activities on a daily basis and these activities are intertwined. When assessed, regarding work environment and conditions, there is a high need for protection in the workplace, where traditional methods are used. There is uneducated and unprotected work force, small-scale family businesses which operate without precautions against various hazards and risks, while prevention and protection services are highly insufficient (CSGB, 2018a). As agricultural activities include open field work, use of chemical content materials, living together with different species of livestock, operation in different weather conditions, use of a large number of agricultural devices and equipment, 
there is prevalence of various diseases transmitted from animals, and so on. So, workers in the field are at more risk than workers in other sectors.

The working environment contains 'physical hazards' from air, land, fire, and machinery as well as 'toxicological hazards' from pesticides, fertilizers and fuels, and hazards from dust (SAKA, 2012). This situation is due to many agriculturespecific factors such as dependence of agriculture on natural conditions, importance of seasonality, density of unpaid family labor, low level of education, and income instability (GULÇUBUK, 2017). Moreover, level of risks and hazards increases due to reasons such as agricultural production being run in an enclosed environment, concentration of seasonal workers, employment of child workers, long working hours, and often use of body power. FENSKE et al. (2002) stated that economic uncertainty in agribusiness and stress due to long working hours are considered as an essential risk factor for injury and chronic diseases. Also, unsafe transportation constitutes a significant occupational health hazard, particularly for farmworkers hired by contractors who are known to use unsafe vehicles and who are also careless, tired, untrained, or unlicensed drivers (PREIBISCH \& OTERO, 2014). For this reason, it is vital to make agricultural workers more secure by taking some precautions beforehand (CSGB, 2018b).

Industrial sectors such as agriculture and construction, where small businesses dominate, are ranked by regulatory agencies among the highest risk categories concerning health and safety (WALTER, 1998). The International Labor Organization pointed out the agricultural sector as one of the most dangerous business branches and annually reports that many agricultural workers have occupational diseases and work accidents (BAKIRCI, 2011). According to the International Labor Organization (ILO) data; 1.3 billion people are working agricultural sector but an average 170,000 of them die each year because of various job accidents and diseases caused by their job (YALCIN et al., 2016; CAMURCU \& SEYHAN, 2015; AKPINAR \& OZYILDIRIM, 2016; BAKIRCI, 2011). According to EUROSTAT, the agricultural sector is considered the second most dangerous sector after the construction sector (YALÇIN et al., 2016; CAMURCU \& SEYHAN, 2015). Agriculture is among the most dangerous sectors in our country. According to the Communiqué on Workplace Hazard Classes Concerning Occupational Health and Safety, a large number of sectors of agriculture, forestry and fisheries are in dangerous class (CSGB, 2018b). According to the 2017 murder of workers report, about 2006 workers lost their lives in Turkey in 2017. Three hundred eight five are in the agriculture and forestry business (ANONYMOUS, 2018a). In July 2018, 195 workers lost their lives, and 28\% (55 people) of these workers are in the agricultural sector (ANONYMOUS, 2018b).

If assessed at the macro level, the agricultural sector is of great importance to the country both economically and socially. It is dependent on the adoption and implementation of measures to protect the health of agricultural workers by ensuring appropriate working conditions regarding the sustainability of the agricultural sector, a sector in which there is a high level of danger and concern. In the agriculture sector, where social and economic importance is too significant to be discussed, work health and safety of employees are too sensitive to be ignored.

The purpose of this study is to investigate the knowledge levels of farmers who operate in agricultural activities that is considered among the most dangerous sectors in Turkey and worldwide, on occupational accidents and occupational diseases, occupational health and safety, as well as to learn about their thoughts and contribute to raise awareness and dissemination of occupational health and safety, in Osmaniye and Konya provinces where intensive agricultural activities take place.

\section{MATERIALS AND METHODS}

The primary material of this study is the data obtained from face-to-face interviews with farmers registered in the Farmer Registration System (FRS) in Osmaniye and Konya provinces. Selected as the working area Osmaniye and Konya are regions in which a high proportion of Turkey's total production in certain agricultural products. Approximately $29 \%$ of sugar beets and $10 \%$ of the total wheat production in Turkey are produced in Konya. In addition, approximately $70 \%$ of radish and $32 \%$ of total groundnut production in Turkey are produced in Osmaniye. These cities were chosen because the agricultural activities look alike. Agricultural products produced in both cities requires human power instead machinery. There are 15,612 farmers registered in FRS in the research area. The purpose of the survey questionnaire prepared for the research was developed considering the content of the questionnaire and the characteristics of the main body to which the questionnaire was applied. This research has also benefited from similar studies in the literature. The sample size of this study was determined by the Simple Random Probability 
Sampling method (ARIKAN, 2017). Sample size according to this method is calculated with the formula given below;

$n=\frac{\left(p * q * z^{2}\right)}{D^{2}}$

According to this formula, the sample size was calculated as 171 with $95 \%$ confidence level $+/-7.5 \%$ error rate. A questionnaire study was conducted with 185 farmers in case of an inaccurate and incomplete questionnaire. The survey took place between November 2017 and April 2018.

The research data were evaluated employing package programs and presented in the form of frequency analyzes, cross tables and Kruskal Wallis $\mathrm{H}$ Test conducted following the purpose of the study. As the obtained data did not show normal distribution, Chi-Square analysis was performed instead of parametric tests. In chi-square analysis, the most important consideration is the fact that more than $20 \%$ of theoretical values are not smaller than 5 (YÜKSELEN, 2006). However, in the Chi-Square analysis, more than $20 \%$ of the theoretical values were smaller than 5 and could not be used and Kruskal Wallis $\mathrm{H}$ test was used instead. The Kruskal Wallis $\mathrm{H}$ test is used to test whether there is a significant difference between the two distributions by comparing the measurements related to dependent one variable of two or more groups independent of each other (URAL \& KILIC, 2006). The Kruskal Wallis H test was applied to see if there was a statistically significant difference between the demographic characteristics of farmers, thoughts on occupational health and safety, and knowledge of the occupational health and safety obligations of farmers.

\section{RESULTS AND DISCUSSION}

Findings obtained after the evaluation of 185 farmed data using face-to-face interview method are presented in this section. First of all, the demographic characteristics of the demographics were assessed by taking into consideration the effects on the people and their practices and behaviors. Demographic characteristics of farmers are shown in table $1.45 .9 \%$ of the farmers involved in the survey are located in the province of Osmaniye, and the remaining part (54.1\%) are in the province of Konya. Among these farmers, $88.1 \%$ are male. The average age of the farmers is divided into 5 groups. Farmers who participated in the survey are mostly age 46 and older. Farmers are mainly graduated from primary, secondary and high school. It is seen that $48 \%$ of the farmers have 1501-3000 TL income. The reasons for
Table 1 - Demographic characteristics of farmers.

\begin{tabular}{lrrcrr}
\hline CITY & f & $\%$ & EDUCATION STATUS & f & $\%$ \\
\hline Osmaniye & 85 & 45.9 & Not literate & 5 & 2.7 \\
Konya & 100 & 54.1 & Primary school & 54 & 29.2 \\
GENDER & $\mathrm{f}$ & $\%$ & Middle school & 51 & 27.6 \\
Male & 163 & 88.1 & High school & 43 & 23.2 \\
Female & 22 & 11.9 & University & 31 & 16.8 \\
AGE & $\mathrm{f}$ & $\%$ & MA / PhD & 1 & 0.5 \\
\hline $16-25$ & 25 & 13.5 & LEVEL INCOME (TL) & $\mathrm{f}$ & $\%$ \\
\hline $26-35$ & 34 & 18.4 & Less than 750 & 19 & 10.3 \\
\hline $36-45$ & 33 & 17.8 & $751-1500$ & 46 & 24.9 \\
$46-60$ & 52 & 28.1 & $1501-3000$ & 89 & 48.1 \\
\hline $60+$ & 41 & 22.2 & $3001-5000$ & 31 & 16.8 \\
\hline
\end{tabular}

such consisted of small family businesses and high input costs of agricultural business in Turkey, which can be considered as a cause of the high proportion of low-income farmers.

While the vast majority of farmers are engaged in agriculture with more than 15 years with $44.3 \%$, it is followed by $28.6 \%$ of those are in agriculture business for 10-15 years. Overall percentage of those who are engaged in agriculture for 5-10 years is $14.6 \%$, and lastly total percentage of those who have been farming for less than 5 years is $12.4 \%$. This showed us that the farmers are mainly engaged in long-lasting agricultural activities. Also, while $75.7 \%$ of farmers have social security, $24.3 \%$ have no social security at all. This figures stated that majority of the farmers have social security.

Occupational health and safety can be defined as the elimination or reduction of health problems and occupational risks that workers are exposed to because of the physical-environment related conditions at work (AKPINAR \& OZYILDIRIM, 2016). Occupational health and safety practices in agriculture include identifying and eliminating risks that cause illness and premature mortality to prevent disease and premature death of workers, while covers measures to reduce the impact if it is not possible to get rid of it (SIMSEK, 2016).

Farmers are asked to define the meaning of the occupational health and safety. Almost half of them $(45.9 \%)$ declared that they have no idea about the subject (Table 2). These numbers showed that farmers had a little or no knowledge about occupational health and safety. When the ratio of the answer in questionnaires "I do not have any idea" is calculated and compared considering the two cities 
Table 2 - Opinions of farmers about Occupation Health and Safety (OHS).

\begin{tabular}{|c|c|c|}
\hline Definitions & $\mathrm{f}$ & $\%$ \\
\hline I do not have any idea & 85 & 45.9 \\
\hline It is educational program aiming to teach necessary precautions for work & 36 & 19.5 \\
\hline Work accidents are the biggest problem of today's world and it is a necessary practice & 36 & 19.5 \\
\hline Receiving training on occupational health and safety avoid work accidents and job-related illnesses & 28 & 15.1 \\
\hline Total & 185 & 100.0 \\
\hline
\end{tabular}

in the study, it was observed that the total percentage of those who stated the answer is $43.5 \%$ in Osmaniye while it is $56.5 \%$ in Konya.

The proportion of farmers who stated "I do not have any idea" in their definitions of occupational health and safety seems to have fallen with the level of education raises. While all non-literate people stated the choice "I do not have any idea," primary, high school, and university graduates predominantly expressed the definition "It is an educational program aiming to teach necessary precautions for work" and "It is receiving training on occupational health and safety to avoid work accidents and job-related illnesses." Secondary school and postgraduate graduates explained the definition to be "Work accidents are the biggest problem of today's world, and it is a necessary practice."

While $75.7 \%$ of the farmers stated that they did not receive occupational health and safety education, $24.3 \%$ of them acknowledged that they got training on the subject. Likewise, $9.2 \%$ of those who got educated on the subject received this education as a part of their undergraduate courses in the university. These results showed that the vast majority of farmers have not undergone any training on occupational health and safety. It was also observed that the ones who have got prior knowledge of the subject received occupational health and safety education through the school, studied and did not make any additional effort. HOPE et al. (1999) indicated that only $8 \%$ of farmers participated in health and safety education in their work in Ireland. AKPINAR \& OZYILDIRIM (2016) indicated that in their study in Trakya region, the rate of occupational accident and occupational disease education was $4.3 \%$. When these studies in the literature were evaluated, it is seen that the ratio of farmers receiving occupational health and safety education in Osmaniye and Konya provinces was rather good.

A rate of $51.1 \%$ of the occupational health and safety education areas are in Osmaniye while $48.9 \%$ are in Konya. It is seen that the farmers who take occupational health and safety education are predominantly young people (Table 3 ).

When farmers involved in the survey are evaluated whether they know the occupational health and safety obligations of agricultural workers; $24.3 \%$ of them answered yes, while $75.7 \%$ answered no (Table 4). It appears that a large majority of farmers do not know the occupational health and safety obligations in agriculture. The information source of the farmers who said "YES" was internet with $68.9 \%$. This is followed by magazines-newspapers, peerfriendly advice and television.

Table 3 - Occupational Health and Safety education by age.

\begin{tabular}{|c|c|c|c|c|c|c|}
\hline \multirow[t]{2}{*}{ Age/OHS Education } & \multicolumn{2}{|c|}{ 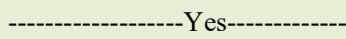 } & \multicolumn{2}{|c|}{ 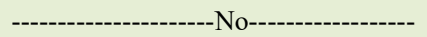 } & \multicolumn{2}{|c|}{--------------------Total- } \\
\hline & $\mathrm{f}$ & $\%$ & $\mathrm{f}$ & $\%$ & $\mathrm{f}$ & $\%$ \\
\hline $16-25$ & 12 & 48.0 & 13 & 52.0 & 25 & 100.0 \\
\hline $26-35$ & 17 & 50.0 & 17 & 50.0 & 34 & 100.0 \\
\hline $36-45$ & 7 & 21.2 & 26 & 78.8 & 33 & 100.0 \\
\hline $46-60$ & 9 & 17.3 & 43 & 82.7 & 52 & 100.0 \\
\hline $60+$ & 0 & 0.0 & 41 & 100.0 & 41 & 100.0 \\
\hline Total & 45 & 24.3 & 140 & 75.7 & 185 & 100.0 \\
\hline
\end{tabular}


A rate of $84.4 \%$ of farmers in occupational health and safety education know the occupational health and safety obligations of workers in agriculture. A rate of $15.6 \%$ of the trainees do not know the occupational health and safety obligations in agriculture. Only 5\% of farmers who are not trained in occupational health and safety know the occupational health and safety obligations of agricultural workers.

A rate of $14.6 \%$ of the farmers in the surveyed enterprises participated in congresses, conferences or symposiums related to occupational health and safety while $85.4 \%$ has not participated in any of them. These meetings were organized by various businesses, Ministry of Agriculture, health and safety experts, certification organizations and municipalities respectively.

A rate of $43.2 \%$ of farmers stated that they had at least one job accident, while $56.8 \%$ has not had any. There were machine accidents (57.3\%), tool and equipment accidents (15.9\%), chemical accidents $(22 \%)$ and ergonomic accidents $(4.9 \%)$ among the work accidents. CHAPMAN \& MEYERS (2001) stated that injuries due to musculoskeletal injuries and illnesses can affect agricultural worker more often and more severely than all other safety and health problems in the remainder of the working years. PREIBISCH \& OTERO (2014) stated that unreasonable productivity targets, partbased wage systems and pressure from management intensifying the production process at a level that would increase the risk of workplace injuries are expressed by study participants.

A rate of $53.3 \%$ received the occupational health and safety training and $40 \%$ of the ones who did not received any occupational health and safety training experienced work accidents. Despite the expectation that occupational health and safety education reduces the rate of work accident incidence, this effect is lower than expected. PREIBISCH \& OTERO (2014) also pointed out that workers receiving occupational health and safety education do not affect the likelihood of injury, and that a trained person returning to a dangerous environment is still exposed to injury risk. Although, one of the main objectives of occupational health and safety training is to minimize accidents and injuries, results obtained from the study and the findings in the literature indicated that the accident and injury rates of the trainees can not to be underestimated.

The rate of farmers who stated that they know occupational diseases in the investigated enterprises is $37.3 \%$, and the rate of those who do not know is $62.7 \%$. A rate of $97.9 \%$ of farmers stated that they did not have any occupational diseases; however, $1.1 \%$ had hearing loss, $0.5 \%$ varicose veins and $0.5 \%$ had diseases spread from steel. These ratios seemed to be quite low, as farmers do not know about occupational diseases predominantly because they do not know that some of their current disabilities are part of the occupational disease definition. FRANK et al. (2004) stated hearing loss caused by exposure to noise, is widespread in farming and affects $55 \%$ to $72 \%$ of the farmer population. The ratio of occupational disease is higher in the literature, but these rates are seen low in Turkey because the farmers do not know what the diseases are.

The percentage of those who use protective clothing in agricultural applications is $70.8 \%$, and the rate of those who do not use them is $29.2 \%$. A rate of $50.3 \%$ of respondents say that the maintenance of tools and equipment used in agriculture is also inadequate. Reed (2004), stated that farmers are

Table 4 - Information sources and the knowledge of farmers about Occupation Health and Safety.

\begin{tabular}{lcc}
\hline Responsibilities of agriculture work regarding OHS & $\mathrm{f}$ & $\%$ \\
\hline Yes & 45 & 24.3 \\
No & 140 & 75.7 \\
Total & 185 & $\mathrm{f}$ \\
Information sources in agriculture & 31 & 100.0 \\
Internet & 4 & 16.8 \\
Friend Advice & 2.2 \\
Television & 8 & 1.1 \\
Newspaper and Magazines & 4.3 \\
No Respond & 140 \\
Total & 185 & 75.7 \\
\hline
\end{tabular}

Ciência Rural, v.49, n.4, 2019. 
aware of personal protective equipment, but their personal preference is not to use this equipment; although, they are satisfied with the availability and cost of equipment. Compared with findings in the literature, these showed a high utilization rate of the protective clothing in Turkey.

The participation of the farmers in the investigated businesses to various considerations on occupational health and safety was assessed and the proportion of farmers who stated that protective clothing should be used when spraying was $78.90 \%$, while $10.3 \%$ of the farmers expressed the unnecessity of wearing them. $92.4 \%$ of those who use protective clothing and $46.3 \%$ of those who do not use indicate that protective clothing should be used when spraying. $73.5 \%$ of the farmers stated that they should receive occupational health and safety education while $9.1 \%$ does not think that occupational health and safety education should be taken.

When an assessment is made according to the occupational health and safety (OHS) education receiving status, $95.6 \%$ of the ones received training and $66.4 \%$ of those with no education on the subject emphasize the necessity of the occupational health and safety education (Table 5). The rate of people who think occupational health and safety practices in Turkey are adequate is $11.3 \%, 36.2 \%$ is undecided, while the rate of people who state practices are poor is $52.4 \%$. While $57.3 \%$ of farmers acknowledged that they do not think the promotion of occupational health and safety in agriculture is sufficient, $28.10 \%$ stated that they are unsure about the adequacy of occupational health and safety education. These results show us that occupational health and safety education should be received, but the promotional activities and applications in Turkey are insufficient.

The Kruskal Wallis H test was applied to see if there was a statistically significant difference between the demographic characteristics of the farmers, the thoughts on occupational health and safety, and the knowledge of the occupational health and safety obligations of farmers. Regarding the cities farmers live, no significant difference was found between the opinions about occupational health and safety and the occupational health and safety obligations of farmers $(p>0.05)$ (Table 6). However, there were significant differences between age and education status regarding occupational health and safety considerations, and knowledge of occupational health and safety obligations of farmers. Young people have more knowledge of the occupational health and safety responsibilities of farmers and are more positive about occupational health and safety. Besides, as the level of education increases, positive thoughts on occupational health and safety are increasing and obligations are well-known.

\section{CONCLUSION}

In agriculture sector which is considered among the most dangerous business lines; reasons such as child labor, seasonal workers, unregistered working and family businesses, long working hours, and often the use of body power, as well as the inability to distinguish between social life and working areas, are the factors, which increase the risk level and danger in agriculture and therefore emphasizing the importance of agricultural health and safety. In this study aimed to investigate farmers' level about knowledge on occupational health and safety in agriculture and their view considering the subject in both cities of Osmaniye and Konya; it was observed that farmers do not have sufficient knowledge about occupational health and safety, they do not know occupational health and safety obligations, and do not take adequate measures against the hazards that may arise during work. In terms of sustainability of agriculture, it is vital to make certain working conditions more secure by taking some precautions beforehand and to give specific standards to workers in terms of safety, health and social means. Although, in agriculture sector of which the social and economic importance is too big to be discussed, occupational health and

Table 5 - The necessity of OHS education according to OHS education receiving status.

\begin{tabular}{lcccccccccccc}
\hline & \multicolumn{2}{c}{ Strongly agree } & \multicolumn{2}{c}{ I agree } & \multicolumn{2}{c}{ Undecided } & \multicolumn{2}{c}{ I disagree } & \multicolumn{2}{c}{ Sstrongly disagree } & Total \\
\hline & $\mathrm{f}$ & $\%$ & $\mathrm{f}$ & $\%$ & $\mathrm{f}$ & $\%$ & $\mathrm{~F}$ & $\%$ & $\mathrm{f}$ & $\%$ & $\mathrm{f}$ \\
Yes & 22 & 48.9 & 21 & 46.7 & 1 & 2.2 & 0 & 0.0 & 1 & 2.2 & 45 \\
No & 27 & 19.3 & 66 & 47.1 & 31 & 22.1 & 11 & 7.9 & 5 & 3.6 & 140 \\
Total & 49 & 26.5 & 87 & 47.0 & 32 & 17.3 & 11 & 5.9 & 6 & 3.2 \\
\hline
\end{tabular}

Ciência Rural, v.49, n.4, 2019. 
Table 6 - Relationship between demographic variables with Occupation Health and Safety knowledge and responsibilities.

\begin{tabular}{|c|c|c|c|c|c|c|}
\hline & $\begin{array}{c}\text { OHS Knowledge } \\
\text { - City }\end{array}$ & $\begin{array}{l}\text { OHS Knowledge } \\
\text { - Age }\end{array}$ & $\begin{array}{c}\text { OHS } \\
\text { Knowledge - } \\
\text { Education status }\end{array}$ & $\begin{array}{c}\text { OHS Responsibilities } \\
\text { - City }\end{array}$ & $\begin{array}{l}\text { OHS Responsibilities } \\
\text { - Age }\end{array}$ & $\begin{array}{c}\text { OHS } \\
\text { Responsibilities - } \\
\text { Education status }\end{array}$ \\
\hline Chi-Square & 2.41 & 28.964 & 22.294 & 0.012 & 29.233 & 35.224 \\
\hline $\mathrm{df}$ & 1 & 4 & 5 & 1 & 4 & 5 \\
\hline Asymp. Sig. & 0.121 & 0 & 0 & 0.911 & 0 & 0 \\
\hline
\end{tabular}

safety of employees is a sensitive issue that cannot be ignored, it seems to be the case that applications and promotions in this area are inadequate. Prevalence of dissemination activities aimed to inform the prevention or reduction of occupational accidents in this sector and taking necessary measures to prevent occupational diseases should be considered as priority issues. The use of the information and Communication Technologies (ICT), especially internet, will disseminate the information about occupational health and safety more rapidly among the society.

It is challenging to sustain any standardization for occupational health and safety in the agricultural sector, whose working fields, times and conditions are very different from other sectors. However, along with the initiatives to be carried out at the ministry level and the organization of agricultural occupational health and safety units at the provincial level, the working conditions and working styles of the employees in the regional agricultural activities may be subject to inspection and supervision. Furthermore, due to sectoral differences, separate legislation related to agricultural occupational health and safety can be created and put into practice. This needs to be extended to cover all regions of the field research, and to be applied according to the application data obtained from the field as well.

\section{BIOETHICS AND BIOSSECURITY COMMITTEE APPROVAL}

We authors of the article entitled " Evaluation of farmers' approaches on occupational health and safety: the case of city of Osmaniye and Konya, Turkey" declared, for all due purposes, the project that gave rise to the present data has not been submitted for evaluation to the Ethics Committee of the Osmaniye Korkut Ata University, but we are aware of the contents of Resolution No. 466, of December 12, 2012 of the Brazilian National Health Council "http://conselho.saude.gov.br/resolucoes/2012/Reso466.pdf" if it involves human. Thus, the authors assume full responsibility for the presented data and are available for possible questions, should they be required by the competent authorities.

\section{DECLARATION OF CONFLICT OF INTERESTS}

The authors declared no potential conflicts of interest with respect to the research, authorship, and/or publication of this article.

\section{ACKNOWLEDGEMENTS}

There is no financial support for this article

\section{AUTHORS' CONTRIBUTIONS}

The authors contributed equally to the manuscript.

\section{REFERENCES}

AKPINAR, T.; OZYILDIRIM, K. Evaluation in the context of occupational health and safety of the farmers who perform agricultural activities in the Thrace Region. Çalışma ve Toplum, v.3, p.1231-1270, 2016.

ANONYMOUS. Report on work murders in 2017: In Turkey, at least two thousand and six workers were murdered in 2017 .. Available from: <http://guvenlicalisma.org/19299-report-onwork-murders-in-2017-in-turkey-at-least-two-thousand-and-sixworkers-were-murdered-in-2017, 2018a>. Accessed: Aug. 8, 2018.

ANONYMOUS. 'Yerli ve milli' ișçi sağlığı politikamızın tablosu. Temmuz ayında en az 195 iş̧̧i yaşamını yitirdi. Accessed. Available from: <http:/guvenlicalisma.org/19620-temmuz-ayinda-en-az-195isci-yasamini-yitirdi, 2018b>. Accessed: Aug. 8, 2018.

ARIKAN, R. Araştırma Yöntem ve Teknikleri (3rd ed.). Ankara: Nobel Yayınevi, 2017.

BAKIRCI, N. Tarımda çalışanların sağlığı ve güvenliği. Türk Tabipleri Birliği Mesleki Sağlık ve Güvenlik Dergisi, Ocak, Şubat, Mart, p.7-13, 2011.

CHAPMAN, L.; MEYERS, J. Ergonomics and musculoskeletal injuries in agriculture: recognizing and preventing the industry's most widespread health and safety problem. In: NATIONAL AGRICULTURE HEALTH \& SAFETY CONFERENCE 2-3 March 2001, Baltimore.

CAMURCU, S.; SEYHAN, G. Occupational health and safety in agriculture. Süleyman Demirel University Journal of Engineering Sciences and Design (Special Issue of 21. National Congress of Ergonomics, Turkey), v.3, n.3, 549-552, 2015.

Ciência Rural, v.49, n.4, 2019. 
CSGB. Tarımda iş sağlığı ve güvenliği el kitabı, T.C. Çalışma ve Sosyal Güvenlik Bakanlığı, Çalışma ve Sosyal Güvenlik Eğitim ve Araştırma Merkezi. Available from: <www.casgem.gov.tr. 2018a>. Accessed: Aug. 6, 2018.

CSGB. Tarımda iş sağlı̆̆ı ve güvenliği rehberi. T.C. Çalışma ve Sosyal Güvenlik Bakanlığı, İș Sağlığı ve Güvenliği Genel Müdürlüğü Politika ve Strateji Daire Başkanlığı. Available from: <https://www. csgb.gov.tr/media/4604/rehber27.pdf.2018b>. Accessed: Aug. 6, 2018.

FRANK, A.L.; MCKNIGHT, R.; KIRKHORN, S.R.; GUNDERSON, P. Issues of agricultural safety and health. Annual Review of Public Health, v.25, p.225-245, 2004.

FENSKE, R.A.; HIDY, A.; MORRIS, S.L.; HARRINGTON, M.J.; KEIFER, M.C. Health and safety hazards in Northwest agriculture: Setting an occupational research agenda. American Journal Of Industrial Medicine Supplement, v.2, p.62-67, 2002.

GULÇUBUK, B. Does act no 6331 on occupational health and safety make impacts on agriculture? International Journal of Social Sciences and Education Research, v.3, n.2, p.573-582, 2017.

HOPE, A.; KELLEHER, C.; HOLMES, L.; HENNESSY, T. Health and safety practices among farmers and other workers: A needs assessment. Occupational Medicine, v.49, p.231-235, 1999.

PREIBISCH, K.; OTERO, G. Does Citizenship status matter in Canadian Agriculture? Workplace health and safety for migrant and immigrant laborers. Rural Sociology, v.79, n.2, p.174-199, 2014

REED, D.B. The risky business of production agriculture health and safety for farmworkers. Aaohn Journal, v.52, n.9, p.401-409, 2004.

SAKA, K. Tarım sektöründe sağlık sorunları, kaza ve hastalık şablonu. 2012. Available from: < https://isgfrm.com/threads/tarimsektorunde-saglik-sorunlari-kaza-ve-hastalik-sablonu.6157>. Accessed: Aug. 6, 2018.

SIMSEK, Z. Tarımda iş sağlığı ve güvenliği çalıştayı. 16-17 April 2015. Şanlıurfa. 2016.

URAL, A.; KILIC, I. Bilimsel Araştırma Süreci ve SPSS ile Veri Analizi (2nd ed.). Ankara: Detay Yayıncılık, 2006.

WALTERS, D. Employeer epresentation on health and safety in small enterprises: A trade union initiative in agriculture. Employee Relations, v.20, n.2, p.164-179, 1998.

YALCIN, G.E.; YAZICI, E.; KARA, F.O.; IPEKCIOGLU, S.; YALCIN, M. Work accidents and illnesses in agriculture. In: XII. ULUSAL TARIM EKONOMISI KONGRESI. 25-27 May, 2016. Isparta.

YÜKSELEN, C. Pazarlama Araştırmaları (3rd ed.). Ankara: Detay Yayıncılık, 2006. 